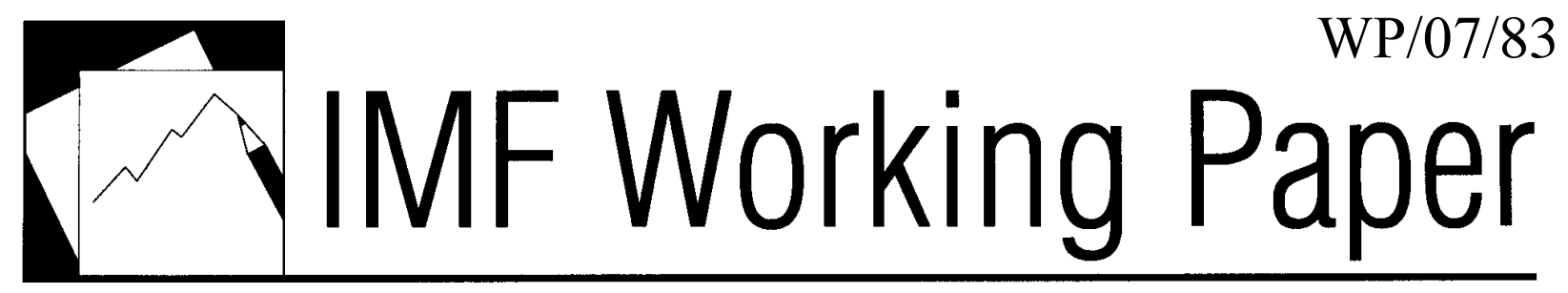

\title{
Land Distribution and Financial System Development
}

\author{
Dietrich Vollrath and Lennart Erickson
}





\title{
IMF Working Paper
}

IMF Institute

\section{Land Distribution and Financial System Development ${ }^{1}$ \\ Prepared by Dietrich Vollrath and Lennart Erickson}

Authorized for distribution by Enzo Croce

April 2007

\begin{abstract}
This Working Paper should not be reported as representing the views of the IMF. The views expressed in this Working Paper are those of the author(s) and do not necessarily represent those of the IMF or IMF policy. Working Papers describe research in progress by the author(s) and are published to elicit comments and to further debate.

Research on credit markets from developing economies, as well as work on the origin of institutions in general, has suggested that land inequality may play a role in determining financial development. In this paper we establish empirically that initial land inequality is a significant predictor of financial depth across countries, even while controlling for other predictors such as legal origin, ethnic fractionalization, and income inequality. To examine this relationship we have created a new measure of land distribution within countries that builds upon the work of Deininger and Squire (1998) by explicitly accounting for landlessness. In addition to being a significant predictor of financial development, land inequality is found to be uncorrelated with other fundamental characteristics of economies, suggesting its possible use in a wider range of research.
\end{abstract}

JEL Classification Numbers: E25, G18, O13, O16, O47

Keywords: Land Distribution, Land Inequality, Financial Development, Financial Institutions Authors’ E-Mail Addresses: devollrath@uh.edu and lerickson@imf.org

\footnotetext{
${ }^{1}$ The authors gratefully acknowledge comments from Andrew Feltenstein and Simon Johnson, as well as from the participants of seminars at the 2006 Western Economic Association Meetings, Rice Univeristy, the University of Houston, and the IMF Institute. Dietrich Vollrath is an Assistant Professor at the University of Houston. Lennart Erickson is an Economist in the IMF Institute.
} 


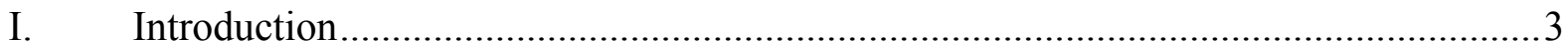

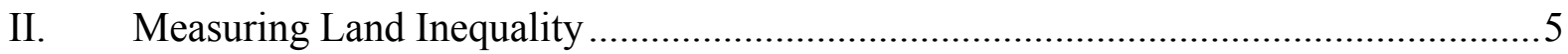

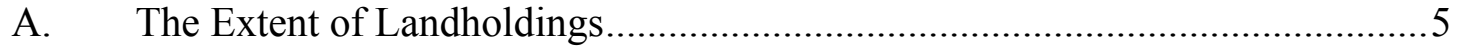

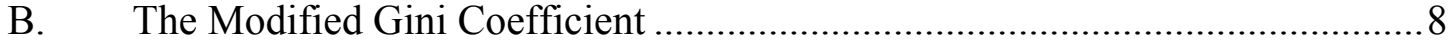

III. Land Inequality and Financial Development ..................................................... 10

A. Financial Depth and Land Inequality........................................................ 11

B. Financial System Efficiency and Land Inequality ...................................... 12

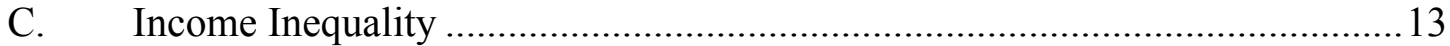

D. Endogeneity of Land Inequality......................................................... 13

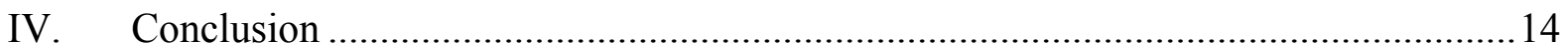

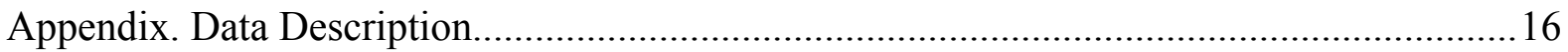

Figures

1. Landholding Gini Coefficient vs. Holdings per EAAp …..................................... 18

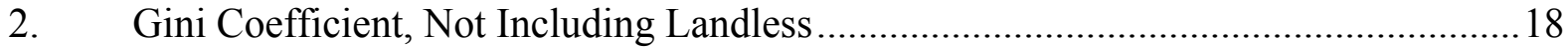

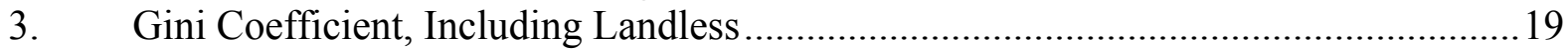

4. DS Landholding Gini Coefficient vs. Overall Land Inequality Gini .........................19

Tables

1. Comparison of Actual Holdings to Different Measures of Potential Holdings ...........20

2. Decadal Means of Holdings per EAAP, by Region, 1960 .......................................21

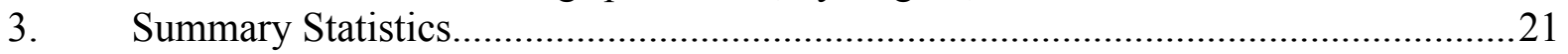

4. Results for Liquid Liabilities ......................................................................22

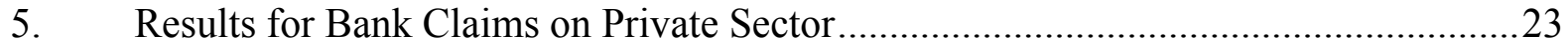

6. Results for All Financial Claims on Private Sector .........................................24

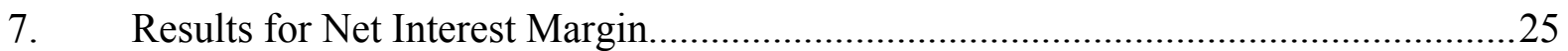

8. Results for Overhead Costs...............................................................................26

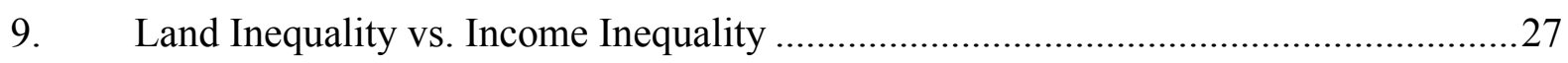

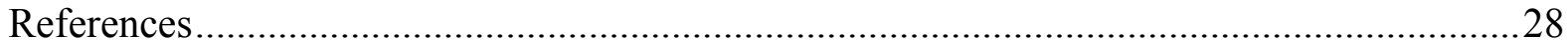




\section{INTRODUCTION}

In developing countries agricultural land accounts for a large portion of total wealth and the distribution of this land has been an object of research for many years. This literature has focused primarily on the consequences of this distribution for household welfare and agricultural efficiency. ${ }^{2}$ The general finding is that inequality in land is detrimental to overall efficiency due to incomplete markets and therefore results in welfare losses to those with little or no land. ${ }^{3}$

The implications of land distribution, though, extend beyond the immediate ones of agricultural production. Credit markets in agricultural areas are subject to informational asymmetries between farmers and lenders, as originally described in Stiglitz and Weiss (1981) and reviewed more thoroughly in Bell (1988) and Besley (1998). Due to these asymmetries, land is required as collateral and thus the distribution of land determines the distribution of credit. Moreover, highly skewed distributions of land will lead to less overall credit, as large landowners are able to self-finance their investments and landless workers are unable to provide the collateral to borrow at all. ${ }^{4}$

Aside from a direct influence on credit transactions, land distribution may influence the institutional structure governing the financial sector. Binswanger, Deininger, and Feder (1995) discuss the great efforts taken by landlords to close off the outside options for their workers. These efforts include using their political power to stall financial reform or limit credit availability to agricultural laborers. In a similar vein, Haber $(1991 ; 1997)$ proposes that the concentrated political power of Mexican and Brazilian landowners allowed them to stall financial development by blocking the introduction of laws conducive to such development (for example, limited liability corporations). Bulmer-Thomas (2003) finds this pattern

\footnotetext{
${ }^{2}$ Among several benefits associated with access to land in developing countries, de Janvry, Platteau, Gordillo, and Sadoulet (2001) list the following: higher incomes, access to secure food supplies, and insurance against price shocks. Besley and Burgess (2000) document that tenancy reforms in India accounted for a 10 percent decline in the poverty gap. Banerjee and Iyer (2005) show how variations in land inequality across India, due to differing British colonial policies, have materially impacted agricultural productivity and income. Berry and Cline (1979) suggest that land distribution is critical to productivity because of the presence of an inverse relationship between farm size and land productivity, which they document for several countries. Vollrath (2007), using cross-country evidence, shows that land inequality has a significant inverse relationship with agricultural output per hectare.

${ }^{3}$ These results have often been cited to support programs of land reform. See Deininger (2001), Otsuka (1991), and Jeon and Kim (2000) for examples of land reform leading to increased agricultural efficiency. de Janvry and Sadoulet (1989) review the various political and institutional reasons why land reforms have failed in Latin America, but they maintain the basic assumption that land reform would be beneficial to agricultural workers.

${ }^{4}$ This effect of wealth distribution on financial depth is considered in the dynamic general equilibrium model of Chakraborty and Ray (2006), who find that increasing inequality in wealth lowers overall financial depth.
} 
repeated across Latin America, where the elite landowners of many countries were disinclined to support measures to increase the efficiency of the financial system. ${ }^{5}$

To examine the broader influence of land distribution on financial development, we develop a new series of data on land inequality across countries that builds on the work of Deininger and Squire (1998) (DS hereafter). Our updated data series adds additional information to the measure of land inequality. As opposed to the DS data, which excluded consideration of the landless, we incorporate them directly into our measure of inequality. We then show that accounting for the landless identifies a strong and robust relationship with financial depth as well as with the efficiency of the banking sector. The new information embodied in our land inequality measure is quite important in this analysis, as the connection of land inequality and financial depth is not apparent when utilizing the existing DS data (see Erickson and Vollrath (2004)).

The contribution of our findings is to identify an important fundamental source of variation in financial development across countries. Given its importance for growth and overall development, a thorough exploration of the origins of financial development seems necessary. ${ }^{6}$ Currently the most prominently cited source is legal origin, developed by La Porta, Lopez-de-Silanes, Shleifer, and Vishny (1997, 1998), but it seems unlikely that this is the sole source of differences in financial development. The results of this paper show that land inequality may have been just as important in determining financial depth across countries.

The paper proceeds as follows. Section 2 discusses in more detail our new measurement of land inequality and the data utilized to create it. Section 3 then uses this new land inequality data to show the relationship between financial development and land inequality and also examines the direction of causation between the two. Section 4 concludes.

\footnotetext{
${ }^{5}$ A related line of research has focused on the role of initial geographic factors on the origin of institutions in general. Acemoglu, Johnson, and Robinson (2001) suggest that the mortality experience of early settlers determined the institutions implemented by colonizers. High mortality areas, such as those found in the tropical regions, were organized as extractive states that left a legacy of poor institutional control. Engerman and Sokoloff (1997) suggest that the type of agriculture available to early settlers in the Americas affected their choice of political structure and property rights. In places conducive to the production of plantation crops such as cotton or sugar, the colonies were organized with land and political power concentrated in the hands a small elite class who actively repressed the development of democracy and education. Easterly and Levine (2003) find empirical support for the idea that initial geographic conditions are significant predictors of subsequent institutional quality. In contrast to the static political effects predicted by these papers, Galor, Moav, and Vollrath (2005) provides a theory of how initial land endowments had a dynamic influence on the economic incentives of countries to develop growth-enhancing institutions such as public education.

${ }^{6}$ The relationship of growth to financial depth and bank credit was documented by King and Levine (1993), while Levine and Zervos (1998) showed that stock market liquidity was associated with growth as well. To deal with endogeneity in the finance/growth relationship, Levine, Beck, and Loayza (2000) used legal origins as instruments for financial sector development, while Beck, Levine, and Loayza (2000) used dynamic panel methods to confirm this finding. A much more thorough review of this line of research can be found in Levine (2005).
} 


\section{Measuring LAND InEQUALity}

The most commonly cited measure of agricultural land inequality is the DS data. This is constructed such that it captures inequality of landholdings over the population of holdings themselves, excluding consideration of the landless. While informative in its own right, it fails to capture the inequality of landholdings across the population of persons who rely on land for their livelihood. We undertake in this section to expand their original inequality measure by using data on the economically active population engaged in agriculture. Our goal is to create a measure of land inequality that incorporates both inequality of farm sizes (as DS do) and inequality in the actual number of farms over the agricultural population (as they do not).

A simple example shows why this update is potentially important. Imagine two countries, A and $\mathrm{B}$, both of which have a population of ten people. In country A, each of the 10 people holds one-tenth of the land. The original DS measure of land inequality would give country A Gini coefficient of zero-perfect equality. In country B, two of the people each hold onehalf of all the land, while the remaining eight hold none. The original DS measure gives country B a Gini coefficient of zero as well. Essentially, their Gini coefficient does not incorporate the eight "holdings" of size zero, and so misses out on relevant data concerning the distribution of land within country B. Given the theoretical considerations, the fact that eight people in country B have no collateral would seem to be of great importance in the development of a financial system in country B. Our results highlight that in fact this new dimension of inequality is in fact important.

\section{A. The Extent of Landholdings}

Measuring the breadth of landholdings in a country requires two pieces of information. First, the number of actual landholdings. Second, the total number of potential landholdings. The first is relatively easy to obtain, while the second will require making assumptions regarding who within a population is a potential landholder.

The number of actual landholdings is obtained from the series of FAO Censuses of Agriculture conducted in rounds every ten years from 1950 to 2000. Each round collects the data from individual country agricultural census reports. ${ }^{7}$ It is from these reports that DS originally created their Gini coefficient for landholdings. In addition to the distribution of holdings by area, these reports contain simple counts of the number of holdings. For 220 of the 275 observations of the Gini coefficient provided by DS we have a matching observation of the number of holdings. For 42 of the DS Gini coefficients we did not obtain the number of holdings because they were from the 1950 round of the FAO Census and we are not able to obtain any relevant population data from prior to 1960. Finally, for 13 of the DS Gini

\footnotetext{
${ }^{7}$ These individual reports do normally not actually correspond to the specific year of the FAO Census round. Thus the 1980 FAO Census contains data from individual reports that occur anywhere from 1975 to 1986 . This variation in reporting dates is not consequential. Knowing the actual year in which each country census took place we can match it to correct year-specific population data.
} 
coefficients we were not able to find a matching observation on number of holdings. Most of these are from the 1980 round of the FAO Census. Since the publication of DS, data from the 2000 round of the FAO Census has become available. From this we have obtained 43 additional observations of both the Gini coefficient on landholdings and the number of landholdings.

The second series of data required is the total number of potential landholdings. While it is not possible to construct a perfect measure for this concept, we do consider two different proxies for this number in an attempt to find a reasonable measure. The first proxy is the number of rural households within a country. It seems reasonable to suppose that the household is the landholding unit, and so the number of rural households is equal to the number of potential landholdings. To the extent that the actual number of landholdings is less than the number of households, then there exist landless households.

Household data by sector is available from the United Nations Demographic Yearbooks of 1987 and 1995. These yearbooks provide 45 observations of the number of rural households within a country. Of these 45 , we are able to merge 29 with an observation of the number of holdings in that country from the FAO census data. ${ }^{8}$

Table 1 displays the results of this exercise in the first column by showing the ratio of holdings to rural households. The average ratio for developing countries is 0.70 , with one observation (Madagascar) showing more holdings than actual households. For developed countries the ratio is generally lower, with an average of only 0.38 . This would indicate that rural landholdings are less equitably distributed within rich countries than within developing countries. That is, there are fewer landholdings available for a given number of rural households in rich countries.

The rural household data have several potential issues. First, rural households are not necessarily agricultural households, and vice versa. ${ }^{9}$ This means we may be miscounting the number of potential landholders in a country. Consider the relatively low ratio of holdings to rural households in rich countries. It seems quite likely that part of the reason for the low values is that there are many households in rural areas that live there with no ties to the agricultural sector. This doesn't necessarily reflect a poor distribution of agricultural landholdings, though. Second, it isn't clear that we should presume that each rural household is a potential user of one landholding. Within an agricultural household there may exist several nuclear family units, each of which could be thought of a potential holder of land. Alternatively, it might be more correct to presume that each person over a certain age in a household could be a potential landholder. In both cases the number of rural households

\footnotetext{
${ }^{8}$ We only matched observations between the UN household data and FAO holdings data if the observations took place within less than 6 years of each other. Adding further observations would require matching observations more than ten years apart in time.

${ }^{9}$ For example, a rural household could be involved in commerce or small-scale manufacturing. By the same token, households in areas classified as urban could work on truck farms.
} 
undercounts the potential number of landholders. Finally, the data on rural households is so limited it precludes any meaningful analysis of the cross-country data.

These concerns lead us to our second proxy for potential number of landholders. This is the economically active agricultural population (EAAP), obtained from the FAO. This is the intersection of estimates by the FAO of the economically active population and the agricultural population. The economically active population includes all employed and unemployed persons, as well as those who are self-employed or working unpaid for family enterprises. The agricultural population is defined as all persons who depend for their livelihood on agriculture, hunting, fishing, or forestry. It may over count the number of people who would be potential holders of land because its definition extends beyond strict agriculture.

We begin by making the simple assumption that each economically active agricultural person is a potential landholder. This has a more intuitive association than number of households. It also does not have the potential problems that the rural household data does. This is an estimate of the agricultural population, not the rural population. It does not depend on the household arrangements of the economically active population. Finally, it is available on a yearly basis for a wide number of countries, allowing us to proceed with a cross-country comparison; this contrasts with the much smaller sample size of the FAO household data.

In Table 1 we have constructed the ratio of number of holdings to the EAAP in the final column. For the developing countries, the average is 0.44 and for every country except Jordan the ratio of holdings to EAAP is lower than the ratio of holdings to rural households. Thus, the number of economically active agricultural workers is larger than the number of households. For the developed countries the average of holdings to EAAP is 0.71 and this is higher than the ratio of holdings to rural households except in Japan in 1975. In the rich countries, then, there are fewer economically active agricultural workers than there are rural households. This would indicate the presence of rural households with no ties to agriculture, a phenomenon that seems likely to be more prevalent in the highly developed countries. We will proceed with using the EAAP as our measure of the potential number of landholdings within a given country in a given year. Combining this with the data on number of holdings we can construct the holdings to EAAP ratio for 220 observations from the DS dataset on landholding inequality. Table 2 summarizes this data with averages given for each of seven regions and for the four rounds of FAO Censuses. From the table we note that the ratio of holdings to EAAP seems to be rising across the whole sample over time, indicating a greater availability of landholdings to economically active agricultural workers. This trend holds for all the individual regions except Sub-Saharan Africa and South Asia.

Comparing this data on the breadth of landholding to the DS data on the concentration of holdings themselves there is an interesting juxtaposition. Those regions identified as having the most equitable distribution of landholdings by DS were Sub-Saharan Africa and East Asia. These regions have the lowest ratio of holdings to EAAP according our data. So while the holdings themselves show little variation in size, there are generally fewer holdings per worker than in other areas. In contrast, those regions identified by DS with the worst distribution of agricultural holdings, Latin America and Eastern Europe, have some of the 
highest ratios of holdings to EAAP. In what is likely not a coincidence, the OECD countries tend to have both low inequality of landholding size according to DS as well as relatively high levels of holdings per EAAP.

This suggests that the holdings per EAAP measure is not simply a proxy for the DS landholding Gini. This can be seen more clearly in Figure 1, which plots holdings per EAAP against the DS landholding Gini. It is apparent from the figure that there is no clear relationship between the two measures of land inequality.

One item that does deserve mention is the fact that there are several observations of holdings per EAAP above one. In other words, there are more holdings than economically active agricultural workers. ${ }^{10}$ The number of holdings measured by the FAO is the number of operational holdings, and it is certainly not impossible that single agricultural workers may operate more than one holding. In the work that follows, we check the robustness of our results by excluding these observations, on the premise that it may indicate a faulty estimate of either the number of holdings or the EAAP. However, we find nothing that indicates the data quality of these countries is any different than the other members of the sample.

Therefore, the EAAP appears to be a decent measure of the potential number of landholders within a country and we proceed with the analysis of the role of land inequality by incorporating this measure of landholding into the existing Gini coefficient estimates.

\section{B. The Modified Gini Coefficient}

The derivation of a modified Gini is best begun by examining the measure employed by DS. Figure 2 shows the standard diagram used in the calculation of the Gini without the landless included.

The distribution of land by share is described by the Lorenz Curve. The landholding Gini of DS uses the distribution of number of holdings and area of holdings to create an estimate of the Lorenz curve. Having calculated the Lorenz curve, they then find the associated Gini coefficient. This Gini - $\mathrm{G}_{\mathrm{DS}}$ - is defined, as according to Figure 2, as

$$
G_{D S}=\frac{A}{A+B}
$$

which can be conveniently rewritten as

\footnotetext{
${ }^{10}$ In particular, there are twelve such observations. Spain (1989), Martinique (1989), Guadeloupe (1989), Italy (1982, 1990), Barbados (1961, 1989), Czechoslovakia (1970), Czech Republic (1990), and Malta (1960, 1969, 1979).
} 


$$
G_{D S}=\frac{(A+B)-B}{A+B}
$$

The area $\mathrm{A}+\mathrm{B}$ is, given the normalizations in the diagram, simply equal to one-half. That results in the following equation for $\mathrm{G}_{\mathrm{DS}}$

$$
G_{D S}=1-2 B
$$

This $\mathrm{G}_{\mathrm{DS}}$ measure the inequality of holding size over all holdings. We would like a modified Gini that measures the inequality of holding size over all potential landholders. What this means is that we need to rescale the Lorenz curve diagram to account for the fact that there are some number of landless people. This modified diagram is seen in Figure 3. The Lorenz curve is now flat from zero up to $1-\frac{\# \text { Hold }}{E A A P}$ which measures the share of potential landholders without land. From $1-\frac{\# \text { Hold }}{E A A P}$ to one, the Lorenz curve is identical to the one found in Figure 2. The overall Gini coefficient, $\mathrm{G}_{\mathrm{OV}}$ is then simply defined as

$$
G_{O V}=\frac{A+C}{A+B+C}
$$

Noting that $A+B+C$ is simply equal to one-half, after some algebra we can write

$$
G_{O V}=2(A+B) \frac{A+C}{(A+B)+C}
$$

From (1) we have an expression for $\frac{A}{(A+B)}$ and by simple geometry we know that $C=\frac{1}{2}-(A+B)$. Substituting these into (5) we can write

$$
G_{O V}=2(A+B) G_{D S}+1-2(A+B)
$$

The area $(A+B)$ is equal to $\frac{1}{2}\left(\frac{\# \text { Hold }}{E A A P}\right)$ and that allows us to reduce (6) to the following expression

$$
G_{O V}=\left(\frac{\# \text { Hold }}{E A A P}\right) G_{D S}+\left(1-\left(\frac{\# \text { Hold }}{E A A P}\right)\right)
$$

Equation (7) shows that the overall Gini coefficient can be viewed as a weighted average of $\mathrm{G}_{\mathrm{DS}}$ and one. The weighting is based on our proposed measure of $\frac{\# \text { Hold }}{E A A P}$ and so the overall Gini is a simple modification of the existing landholding Gini of DS. Using our data we are able to calculate $\mathrm{G}_{\mathrm{OV}}$ for each observation. It is this $\mathrm{G}_{\mathrm{OV}}$ that we will use primarily in the 
following sections to address the influence of overall land inequality on economic development and growth.

Figure 4 plots $G_{O V}$ against $G_{D S}$. As can be seen there is a general tendency for $G_{O V}$ to be higher than $\mathrm{G}_{\mathrm{DS}}$, except for those twelve observations in which holdings per EAAP is actually greater than one. The adjustment to $\mathrm{G}_{\mathrm{DS}}$ is stronger for those observations with an initially low $\mathrm{G}_{\mathrm{DS}}$, as expected. ${ }^{11}$ The mean of $\mathrm{G}_{\mathrm{OV}}$ is 0.81 with a standard deviation of 0.14 . The mean of $G_{D S}$ is 0.65 with a standard deviation of 0.17 . The higher average value of $\mathrm{G}_{\mathrm{OV}}$ is also associated with a smaller dispersion of observations than with $\mathrm{G}_{\mathrm{DS}}$. So variation in land inequality across countries is lower when we account for the landless, excepting several European countries in which $\frac{\# \text { Hold }}{E A A P}>1$.

\section{LAND INEQUALITY AND FinANCIAL DEVELOPMENT}

Using our updated measure, we now address the question of whether land inequality exerts any influence on the development of the financial sector across countries. We have multiple observations of $\mathrm{G}_{\mathrm{OV}}$ for many countries, however, we generally have only a single observation available for the financial variables. This leaves us with the issue of selecting exactly how to generate a $\mathrm{G}_{\mathrm{OV}}$ observation. We follow Deininger and Squire in choosing to use the earliest available observation of land inequality as our base observation. We limit our observations to those countries for which the earliest observed $\mathrm{G}_{\mathrm{OV}}$ comes from before 1980 . We do this because we are interested in initial land inequality and its effect on financial development. In addition, because the financial variables are generally averages over the time frame of 1980-1995, this will give us some confidence that the regressions are not biased by endogeneity, although we return to that subject in more detail later.

Our interest lies in identifying the role that land inequality has played in financial development, and to do this we will use a sample of countries that were all heavily agricultural at the beginning of the post-war era. This excludes the nations of Western Europe, Japan, the United States, Canada, Australia, and New Zealand. While we believe that the effect of land inequality may linger even well after agriculture has declined in importance, measures of land inequality from the 1960's or 1970's from these countries most likely do not fully reflect the land distributions that obtained during the formative years of their financial systems. These exclusions leave us with a small sample of only 44 countries. $^{12}$ Summary statistics for all variables used in this section can be found in Table 3.

\footnotetext{
${ }^{11}$ To see this, note that if $\mathrm{G}_{\mathrm{DS}}=1$ then $\mathrm{G}_{\mathrm{OV}}$ reduces to one as well. The number of landless people is meaningless in a case where all land is held by a single person (technically by a share of people that is of measure zero).

${ }^{12}$ While we have data for one additional country, Malaysia, it appears a distinct outlier in all the regressions. We have no reason to question the financial data for Malaysia, and there is nothing immediately apparent in the land distribution data to indicate mismeasurement.
} 


\section{A. Financial Depth and Land Inequality}

Our first step is to examine the relationship between land inequality and the size of the financial system. Following Levine (1997), we will focus on broad measures of financial depth. The first is the size of liquid liabilities relative to GDP, which varies from 8 percent (Zaire) to 99 percent (Jordan). Our second measure of financial depth is the size of claims on the private sector by deposit banks relative to GDP, and again Zaire has the lowest observed value (1 percent), and Jordan the highest (55 percent). The final measure of financial depth is the size of claims on the private sector by both banks and other financial institutions relative to GDP. While Zaire is once again at the bottom of the distribution (1 percent), South Korea is at the top, with a value of 81 percent. Descriptions of the sources of all data are found in the Appendix.

The results of OLS regressions in Table 4 show a robust relationship of land inequality to liquid liabilities. Column (1) shows the strong correlation of the $\mathrm{G}_{\mathrm{OV}}$ measure developed in this paper to the liquid liabilities measure. This relationship is weakened in column (2) by the inclusion of controls for legal origins, but is strengthened both in significance and in the size of the coefficient by the inclusion of a measure of institutions in column (3). Geographic variables (latitude and landlocked status) are included in column (4), and this again highlights the significant relationship of land inequality to financial depth. Column (5) includes all the controls, and shows again a strongly significant result. Using the estimated coefficient on $\mathrm{G}_{\mathrm{OV}}$ in column (5), a decrease in $\mathrm{G}_{\mathrm{OV}}$ from El Salvador's value (the 75 th percentile) to Cote d'Ivoire's value (the 25 th percentile) is associated with an increase in liquid liabilities as a percent of GDP of 12.7 percent, or approximately two-thirds of a standard deviation. The effect of land inequality on financial depth appears to be not only statistically significant, but economically significant as well.

Column (6) of Table 4 displays the regression of liquid liabilities on all controls, without land inequality included. This shows how much less of the variation in liquid liabilities across countries can be accounted for. The R-squared drops from 42 percent in column (5) to only 29 percent in column (6). Finally, column (7) shows the same regression, only with the original $\mathrm{G}_{\mathrm{DS}}$ measure used to control for land inequality. As can be seen, there is now a much smaller effect, and it is no longer statistically significant. The fact that the results differ so distinctly between the measures indicates that the additional inequality captured by our measure is highly relevant for the development of financial markets. Leaving aside the actual distribution of farm sizes, the number of farms relative to the size of the agricultural population appears to have a significant impact on financial depth. This provides some support for the theories that suggest that the availability of collateral is of importance for access to financial markets. It also suggests that reforms that allocate farms more widely could have positive effects on financial development.

The pattern of results found for liquid liabilities are followed closely when we turn in Table 5 to regressions using claims on the private sector by banks as our dependent variable. Again, while the significance on land inequality falls when only legal origins are included, the relationship of land inequality and financial depth is very strong in the full specification in column (5). The size of the effect is again quite large. Dropping land inequality from the $75^{\text {th }}$ 
to the $25^{\text {th }}$ percentile of the distribution is associated with an increase in private sector claims of 8 percent, around two-thirds of a standard deviation.

One difference from the previous results is found in column (7). Here we see that the original measure of land inequality, $\mathrm{G}_{\mathrm{DS}}$, is significantly and negatively related to financial depth. This indicates that the distribution of agricultural land, holding constant the actual number of farms, is a potentially relevant factor for financial depth.

Table 6 presents similar regressions for our final measure of financial depth, the size of claims on the private sector by banks and other financial institutions. Here, the results are not as significant as seen previously. In the full specification in column (5), the coefficient on land inequality is not significant at 10 percent. Comparing the results of Table 6 to Table 5, we appear to have some evidence that land inequality is quite relevant for the development of the banking system, but that the extent of the rest of the financial system is not affected by land inequality. The theories cited in the introduction do not provide any guidance on this distinction and we look at this as an open research question.

The evidence in Tables 4 and 5 suggests strongly that land inequality is detrimental to the depth of the financial system. This confirms the predictions of much of the theoretical work linking these two in an inverse relationship. However, this does not indicate by what channels land inequality may be acting on the financial sector. We take this up in the following section.

\section{B. Financial System Efficiency and Land Inequality}

One possibility is that land inequality has acted to decrease efficiency in the financial market. That is, land inequality has led to laws or institutions that limit the financial system from functioning smoothly. To examine this possibility, we use data on the efficiency of the banking system by country. Levine and Demirguc-Kunt (2001) use overhead costs relative to bank assets, and bank net interest margin as measures of efficiency. For both variables, increasing values indicate inefficiency.

Table 7 reports regressions of net interest margin on land inequality and the different sets of controls used previously. As can be seen, there is a very highly significant positive relationship between the net interest margin and land inequality, indicating that land inequality is a strong predictor of the inefficiency of the financial system. The size of this effect is very large. A drop in land inequality from the $75^{\text {th }}$ to the $25^{\text {th }}$ percentile would lower the net interest margin by one standard deviation. This provides strong evidence that the effect of land inequality on overall financial depth is through its effect on the efficiency of the financial system.

Similar results are found in Table 8, which reports results using overhead costs relative to bank assets as the dependent variable. While not as significant as the results for net interest margin, we again find very consistent point estimates, significant at 10 percent in nearly all the specifications. Matching the results on net interest margin, Table 8 shows that land inequality has a significant relationship with financial sector efficiency. 
The results of Tables 7 and 8 provide tentative support for the idea that land inequality acts to limit financial development mainly by making the financial sector less efficient, although the data available here does not allow us to say that this is the only channel by which land inequality affects the financial sector.

\section{Income Inequality}

One concern with the interpretation of these results is that the measure of land inequality is simply a proxy for income inequality. Thus, the results cannot be used to say definitively that land inequality matters for financial development. To address this, we include a Gini coefficient for income inequality from Deininger and Squire (1998) in the specifications. The results of this are in Table 9. The first three columns of this table show regressions of the three different measures of financial depth on land inequality, income inequality, and the full set of controls used in prior regressions. Limited data means that the sample is now only 32 countries.

In column (1) the estimated coefficient on $\mathrm{G}_{\mathrm{OV}}$ is no longer significant. However, columns (2) and (3) show that controlling for income inequality actually highlights an even more powerful connection between land inequality and both claims by banks on the private sector and claims by banks and other financial institutions on the private sector. The point estimate on $\mathrm{G}_{\mathrm{OV}}$ in columns (2) and (3) is much higher in these regressions than is found in Tables 5 and 6 , respectively.

Interestingly, the point estimate for income inequality is found to be significantly positive in columns (2) and (3). Thus there is evidence that increases in income inequality are associated with more expansive financial systems. This positive connection is consistent with classical theories of development that suggest richer individuals have higher marginal propensities to save. It highlights a possible second-order effect of opposite sign between the land inequality and finance. This could occur if decreasing land inequality were to lead in turn to lower income inequality.

Columns (4) and (5) of Table 9 show that the relationship of financial sector efficiency to land inequality is robust to the inclusion of income inequality as well. The point estimates are nearly identical to those found in the regressions of Tables 7 and 8 that excluded income inequality.

\section{Endogeneity of Land Inequality}

A general concern in this type of analysis is the possible endogeneity of the explanatory variables. In this case our main method of dealing with this is in the construction of the dataset. As noted previously, $\mathrm{G}_{\mathrm{OV}}$ is taken as the earliest observed value from prior to 1980 for any given country. The financial variables we are using as dependent variables are averages over the period $1980-95$, so that $\mathrm{G}_{\mathrm{OV}}$ is always observed prior to the dependent variable. 
To further address the endogeneity of $\mathrm{G}_{\mathrm{OV}}$ would require a valid instrument that plausibly has a causal effect on $\mathrm{G}_{\mathrm{OV}}$ while having no effect on financial development. Naturally, there are not a plethora of candidates. Even so, the few potential instruments available all appear to be too weak to be useful. There are two primary candidates we have identified.

- Settler Mortality. This comes from the work of Acemoglu et al. (2001) and has been used often as an instrument for institutions themselves. Their premise is that the disease environment at the time of colonization is closely related to the type of institutions imposed by the colonizer. It seems possible that land inequality may have been similarly influenced, with countries with high mortality to settlers imposing high land inequality because they did not settle broadly. This relationship, though, is not borne out in the data. For a sample of countries having observations of both settler mortality and land inequality, a simple regression of $\mathrm{G}_{\mathrm{OV}}$ on the log of settler mortality in an Fstatistic of only 0.05 , with a p-value of 0.83 . This lack of relationship holds for other first-stage regressions including different sets of excluded exogenous variables as well.

- Crop/Mineral Dummies. These were developed by Easterly and Levine (2003) as instruments and controls for regressions concerning institutional quality. Following the research of Engerman and Sokoloff (1997), it would seem plausible to think that there is a connection of land inequality to the type of agriculture and mining done. In places with endowments conducive to the production of plantation crops or point-specific mineral resources, ES conjecture that the elite would have instituted a severely unequal system of both property rights and political rights in order to maintain their control over the resources. Thus we might expect that the type of crops or minerals present in the economy determined land inequality. However, we have found no case in which a firststage regression including the crop/mineral dummies as exogenous instruments provides an F-statistic greater than 1.06. Any second-stage results based on this has essentially no meaning.

Without any clear instrument available, we fall back to the position that the temporal ordering of the independent and dependent variables provides a level of control for endogeneity that allows us to at least tentatively conclude that land inequality has a significant influence on the level of financial development within developing countries. While we cannot be entirely confident that this connection is causal, the results are consistent with the implications of development theory and the broader connections of finance and inequality outlined by Chakraborty and Ray (2005). The fact that land inequality appears not to be correlated settler mortality and crop/mineral dummies is also interesting in and of itself; land inequality may thus offer information beyond that contained in these other measures.

\section{Conclusion}

The role of financial markets in economic development has been highlighted at both the micro and macro levels many times. Research at the country level has generally used legal origins as an exogenous source of financial structure variation. This paper looks back to the economic development literature to identify a second source of variation in financial structure, the distribution of land within a country. 
To address this connection empirically, we developed a new measure of land inequality by country. Our measure expands upon the previous work of Deininger and Squire by including an explicit accounting for the distribution of land over the available population, including the landless. This new measure of land inequality is found to be significantly and negatively associated with measures of financial depth and banking sector efficiency. The estimates suggest a substantial practical significance to the role of land inequality as well. Moving from the 75 th percentile of land inequality down to the 25 th percentile is associated with an increase in liquid liabilities as a percent of GDP of nine percentage points, about one half a standard deviation. The same change in land inequality is also associated with an increase in private credit from banks as a percent of GDP of nearly 7.5 percentage points, or about one third a standard deviation.

Land inequality is also found to significantly influence the efficiency of the banking sector, being associated with both higher net interest margins and higher overhead costs of banks across countries.

The findings in this paper are an attempt to provide a richer explanation of where the variation in fundamental financial development of nations came from. In addition, the finding that our land inequality measure is uncorrelated with other fundamental explanations of development suggests its possible usefulness in future research. Finally, in terms of broad policy implications, the results of this paper provide additional support for those promoting land reforms, as the benefits of these reforms may be much wider than previously thought. 


\section{APPENDIX}

\section{DATA DESCRIPTION}

Liquid Liabilities / GDP: From Levine and Demirguc-Kunt (2001) (LD hereafter). Liquid liabilities equals currency plus demand and interest-bearing liabilities of banks and other financial intermediaries. Average values from 1980-95. This is a broad measure of financial development, including liabilities of the central bank, deposit banks, and all other financial institutions. The raw data for this comes from the IMF's International Financial Statistics (IFS) database.

Private Credit by Deposit Banks / GDP: From LD. This captures the size of claims on the private sector only by deposit money banks. Average values from 1980-95. It excludes claims on the government or public institutions, and excludes claims on the private sector by the central bank. It is thus a clearer measure of the size of the private financial sector. The raw data for this comes from the IMF's IFS database.

Private Credit by Deposit Banks and Other Financial Institutions / GDP: From LD. This measures the size of claims on the private sector by both banks and all other financial institutions, excluding the central bank. Average values from 1980-95. This variable is a slightly broader measure of the size of the private financial services market. The raw data is from the IMF IFS database.

Overhead Costs / Total Bank Assets: From LD. Average values from 1980-95. This measures the accounting value of banks' overhead costs relative to their total reported assets, capturing their efficiency. The raw data comes from the IBCA's Bankscope database.

Net Interest Margin: From LD: This is measured as the accounting value of banks net interest revenue as a share of total bank assets. Average values from 1980-95. This variable is intended to capture efficiency of the banking sector, the implication being that increases in net interest margin indicate a lack of competition. The raw data are from the IBCA's Bankscope database.

Legal Origins: From La Porta et al. (1997): Dummy variables are constructed for each country based on the set of laws forming the basis of the financial system in that country. For our purposes, we group all countries into three categories: French Civil Law, German Civil Law, and Other. The other category includes British common law, Scandinavian common law and Socialist law. The regressions report coefficients for the French and German law dummies, which are to be interpreted as the effect of these systems relative to the Other category.

Institutions: From Kaufman et al (1999): This index is the average value of six different indicators of institutional quality: voice and accountability, political stability, government effectiveness, regulatory quality, rule of law, and control of corruption.

Latitude: This is the absolute value of the latitude of the centroid of the country. 
Landlocked: This is a dummy variable with 1 indicating landlocked and 0 indicating access to an ocean. The landlocked countries in our sample are: Mali, Niger, Paraguay, and Uganda.

Income Gini: From Deininger and Squire (1998). This is the average of all the "high-quality" observations of the income Gini. Deininger and Squire analyzed the techniques used in calculating the income Gini from national surveys to arrive at a set of observations that fulfilled criteria allowing for cross-country comparisons. See their paper for more details on these criteria. 
Figure 1. Landholding Gini Coefficient vs. Holdings per EAAP

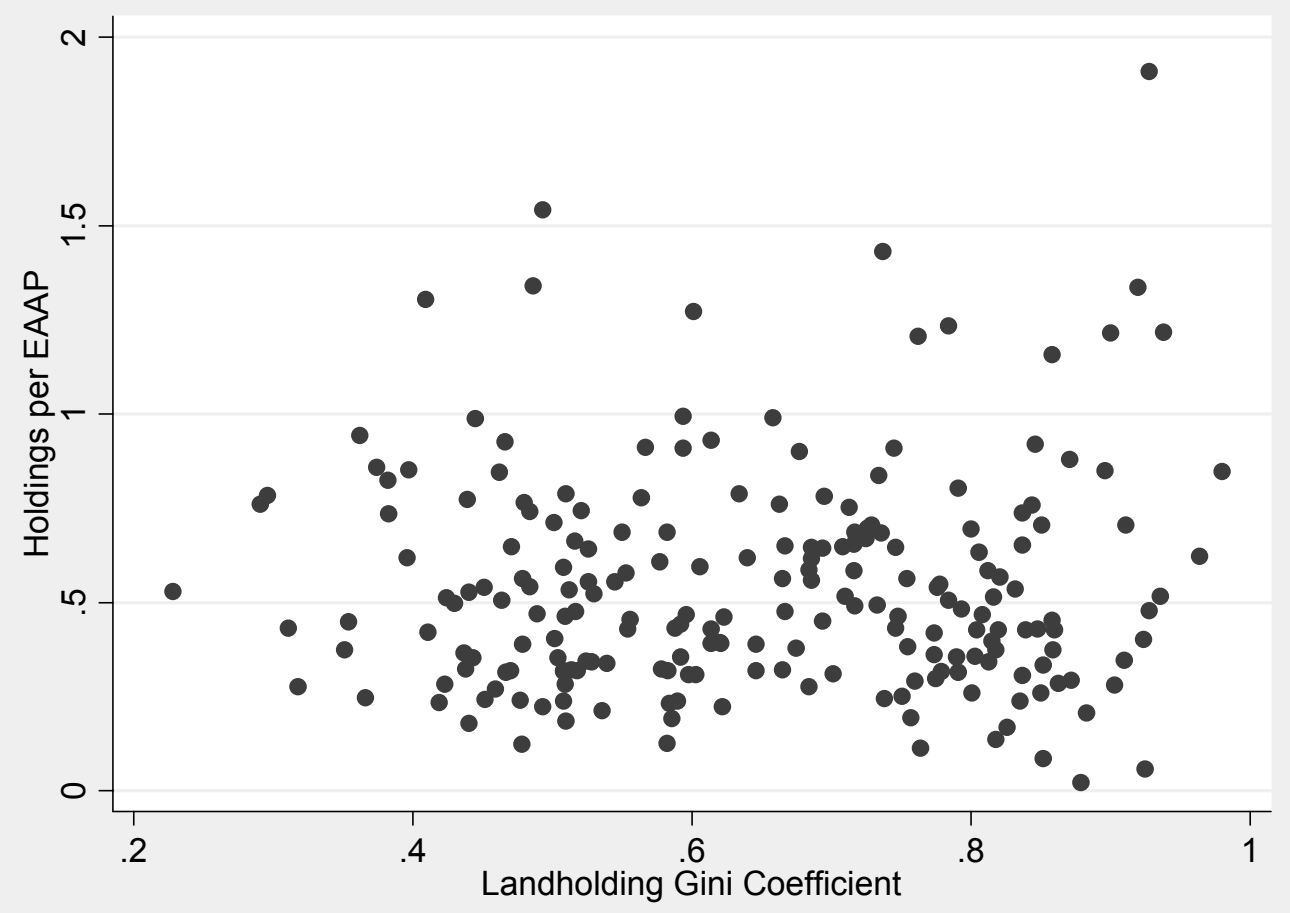

Figure 2. Gini Coefficient, Not Including Landless

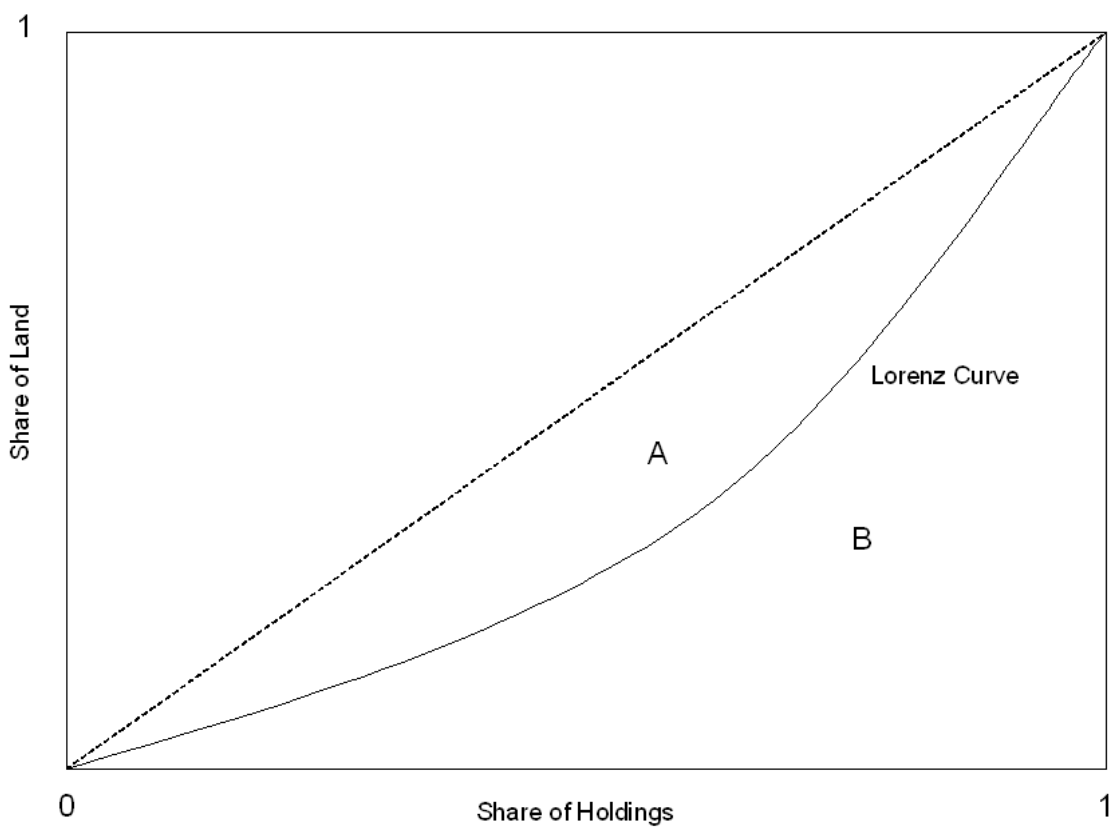


Figure 3. Gini Coefficient, Including Landless

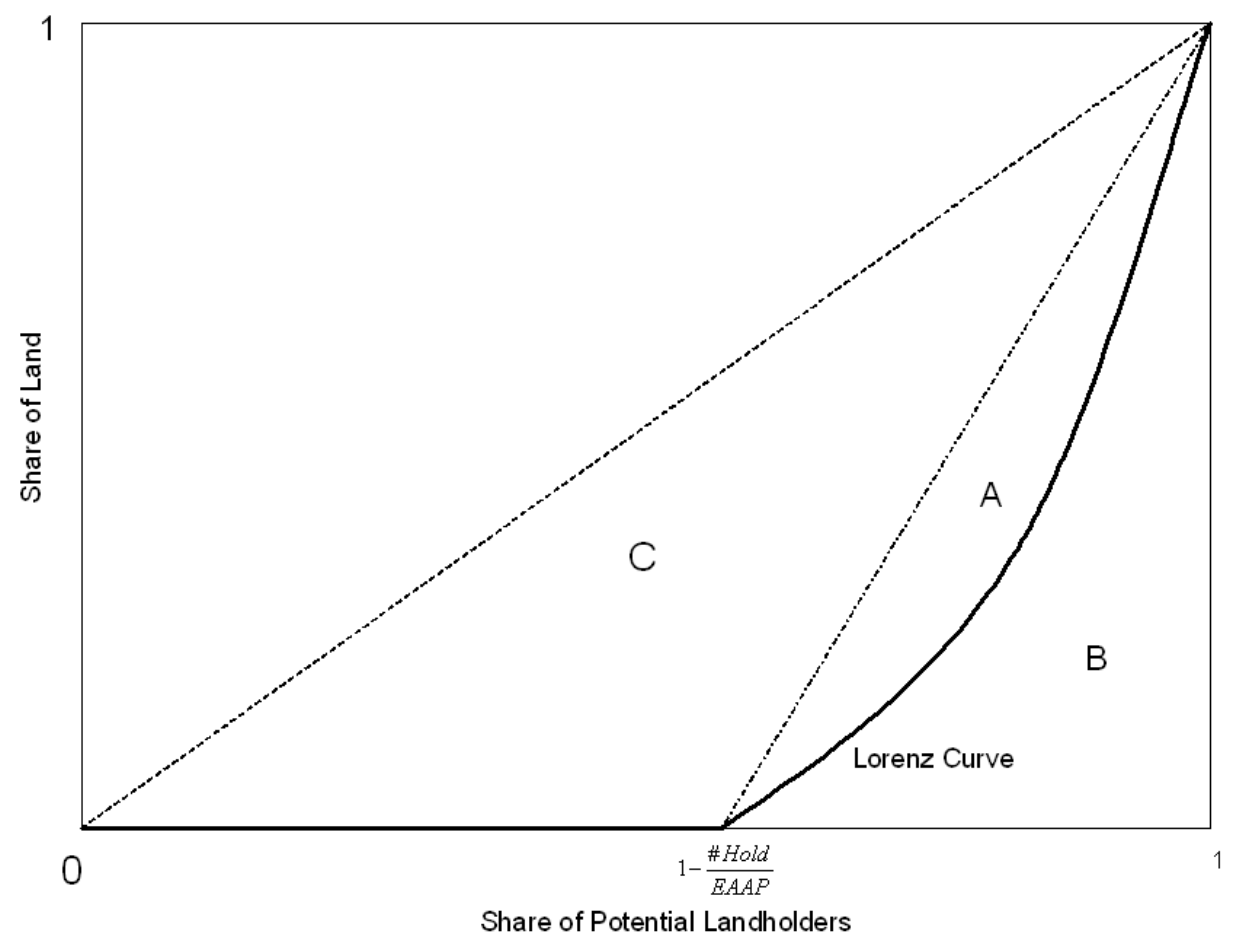

Figure 4. DS Landholding Gini Coefficient vs. Overall Land Inequality Gini

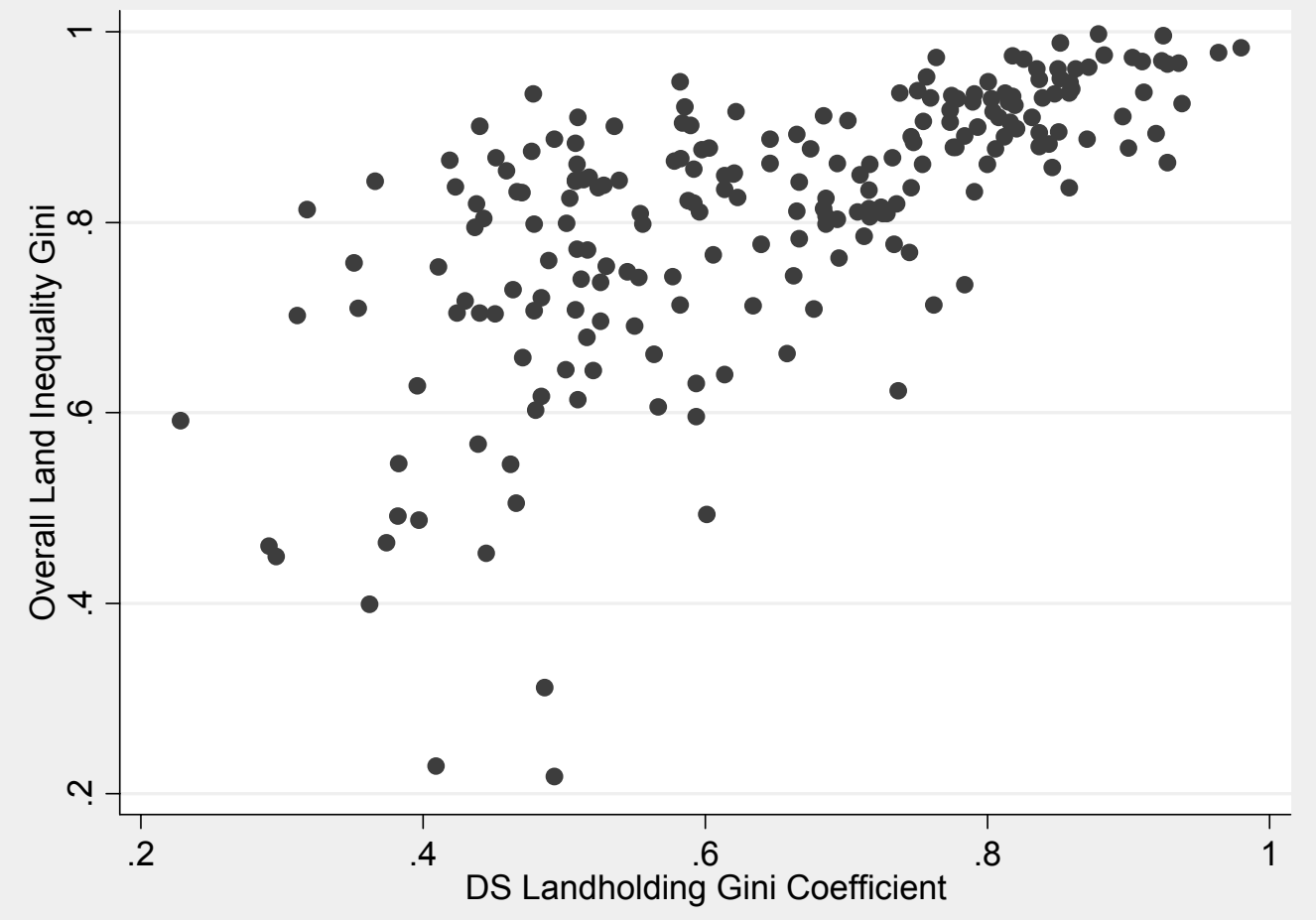


Table 1. Comparison of Actual Holdings to Different Measures of Potential Holdings

\begin{tabular}{|c|c|c|c|}
\hline Country & Year & $(($ Hold $) /(\#$ Rural HH $))$ & $(($ Hold $) /(\#$ EAAP $))$ \\
\hline \multicolumn{4}{|c|}{ Developing Countries } \\
\hline Argentina & 1980 & 0.34 & 0.26 \\
\hline Bangladesh & 1981 & 0.54 & 0.23 \\
\hline Botswana & 1991 & 0.75 & 0.36 \\
\hline Brazil & 1980 & 0.74 & 0.33 \\
\hline Cyprus & 1992 & 0.8 & 0.79 \\
\hline India & 1981 & 0.91 & 0.39 \\
\hline Indonesia & 1980 & 0.6 & 0.45 \\
\hline Israel & 1983 & 0.79 & 0.59 \\
\hline Jordan & 1979 & 0.49 & 0.62 \\
\hline Madagascar & 1975 & 1.1 & 0.43 \\
\hline Namibia & 1991 & 0.63 & 0.39 \\
\hline Nepal & 1981 & 0.9 & 0.32 \\
\hline Pakistan & 1980 & 0.45 & 0.21 \\
\hline Panama & 1980 & 0.94 & 0.76 \\
\hline Philippines & 1980 & 0.63 & 0.34 \\
\hline Poland & 1978 & 0.7 & 0.53 \\
\hline Poland & 1988 & 0.92 & 0.74 \\
\hline South Korea & 1980 & 0.65 & 0.37 \\
\hline Uganda & 1991 & 0.57 & 0.24 \\
\hline Uruguay & 1985 & 0.64 & 0.36 \\
\hline Mean & & 0.70 & 0.44 \\
\hline \multicolumn{4}{|c|}{ Developed Countries } \\
\hline Austria & 1981 & 0.3 & 0.9 \\
\hline Canada & 1986 & 0.15 & 0.58 \\
\hline Finland & 1975 & 0.37 & 0.77 \\
\hline France & 1975 & 0.35 & 0.76 \\
\hline France & 1982 & 0.26 & 0.64 \\
\hline Japan & 1975 & 0.79 & 0.51 \\
\hline Japan & 1980 & 0.62 & 0.74 \\
\hline Japan & 1985 & 0.5 & 0.82 \\
\hline Norway & 1990 & 0.23 & 0.73 \\
\hline Switzerland & 1990 & 0.14 & 0.54 \\
\hline Mean & & 0.38 & 0.71 \\
\hline
\end{tabular}

Number of holdings is from FAO Agricultural Census (various years).

Number of rural households is from UN Population Yearbooks, Vol. 39 (1987) and Vol. 47 (1995).

Number of economically active agricultural population (EAAP) is from FAO. 
Table 2. Decadal Means of Holdings per EAAP, by Region, 1960

\begin{tabular}{lccccc}
\hline \multicolumn{1}{c}{ Region } & 1960 & 1970 & 1980 & 1990 & All \\
\hline Sub-Saharan Africa & 0.337 & 0.0394 & 0.314 & 0.276 & 0.339 \\
South Asia & 0.351 & 0.427 & 0.355 & 0.292 & 0.352 \\
East Asia / Pacific & 0.375 & 0.400 & 0.416 & 0.542 & 0.41 \\
Middle East \& North Africa & 0.434 & 0.308 & 0.468 & 0.308 & 0.416 \\
Latin America & 0.452 & 0.475 & 0.536 & 0.719 & 0.527 \\
OECD and High Income & 0.654 & 0.684 & 0.727 & 0.722 & 0.697 \\
Eastern Europe & 0.523 & 0.783 & 0.847 & 1.335 & 0.842 \\
All & 0.484 & 0.535 & 0.557 & 0.627 & 0.542 \\
\hline
\end{tabular}

Regions are ordered by value in 1980 .

Data are from authors' calculations described in text.

Table 3. Summary Statistics

\begin{tabular}{lccccc}
\hline \multicolumn{1}{c}{ Variable } & & & & & \\
& Number & Mean & SD & Min & Max \\
\hline $\mathrm{G}_{\mathrm{OV}}$ & 45 & 0.88 & 0.06 & 0.71 & 0.98 \\
$\mathrm{G}_{\mathrm{DS}}$ & 45 & 0.69 & 0.16 & 0.32 & 0.94 \\
Liquid Liabilities / GDP & 45 & 0.37 & 0.19 & 0.09 & 0.99 \\
Bank Credit to Private/GDP & 45 & 0.26 & 0.15 & 0.01 & 0.63 \\
Total Credit to Private/GDP & 45 & 0.31 & 0.19 & 0.01 & 0.81 \\
Net Interest Margin & 38 & 0.05 & 0.02 & 0.007 & 0.12 \\
Overhead Costs / Assets & 39 & 0.05 & 0.03 & 0.02 & 0.12 \\
Institutions & 45 & -0.12 & 0.64 & -1.98 & 1.12 \\
Absolute Latitude & 45 & 18.02 & 11.61 & 0 & 41.2 \\
Landlocked Dummy & 45 & 0.04 & 21 & 0 & 1 \\
Income Gini & 33 & 0.45 & 0.08 & 0.31 & 0.62 \\
\hline
\end{tabular}


Table 4. Results for Liquid Liabilities

\begin{tabular}{|c|c|c|c|c|c|c|c|}
\hline \multirow[b]{2}{*}{ Explanatory Variables } & \multicolumn{7}{|c|}{ Dependent Variable: Liquid Liabilities / GDP } \\
\hline & 1 & 2 & 3 & 4 & 5 & 6 & 7 \\
\hline $\mathrm{G}_{\mathrm{OV}}$ & $\begin{array}{c}-0.94 * * \\
(2.30)\end{array}$ & $\begin{array}{l}-0.91 \\
(1.55)\end{array}$ & $\begin{array}{c}-1.27 * * \\
(2.10)\end{array}$ & $\begin{array}{c}-0.90^{* *} \\
(2.03)\end{array}$ & $\begin{array}{c}-1.28^{* *} \\
(2.09)\end{array}$ & & \\
\hline $\mathrm{G}_{\mathrm{DS}}$ & & & & & & & $\begin{array}{c}-0.17 \\
(1.28)\end{array}$ \\
\hline French legal origin & & $\begin{array}{l}-0.07 \\
(1.22)\end{array}$ & $\begin{array}{l}-0.03 \\
(0.59)\end{array}$ & & $\begin{array}{l}-0.03 \\
(0.49)\end{array}$ & $\begin{array}{l}-0.06 \\
(1.19)\end{array}$ & $\begin{array}{l}-0.05 \\
(0.94)\end{array}$ \\
\hline German legal origin & & $\begin{array}{l}-0.10 \\
(1.00)\end{array}$ & $\begin{array}{c}-0.25^{* *} \\
(2.32)\end{array}$ & & $\begin{array}{c}-0.25^{* *} \\
(2.08)\end{array}$ & $\begin{array}{l}-0.04 \\
(0.64)\end{array}$ & $\begin{array}{l}-0.10 \\
(1.18)\end{array}$ \\
\hline Institutions & & & $\begin{array}{c}0.17 * * \\
(4.38)\end{array}$ & & $\begin{array}{c}0.16^{* *} \\
(4.36)\end{array}$ & $\begin{array}{c}0.14 * * \\
(3.94)\end{array}$ & $\begin{array}{c}0.16^{* *} \\
(3.85)\end{array}$ \\
\hline Absolute latitude & & & & $\begin{array}{c}0.00 \\
(1.27)\end{array}$ & $\begin{array}{c}0.00 \\
(0.01)\end{array}$ & $\begin{array}{c}0.00 \\
(0.05)\end{array}$ & $\begin{array}{c}0.00 \\
(0.06)\end{array}$ \\
\hline Landlocked & & & & $\begin{array}{c}-0.19^{* *} \\
(3.97)\end{array}$ & $\begin{array}{l}-0.08 \\
(0.86)\end{array}$ & $\begin{array}{l}-0.07 \\
(1.50)\end{array}$ & $\begin{array}{l}-0.08 \\
(1.11)\end{array}$ \\
\hline Constant & $\begin{array}{l}1.19^{* *} \\
(3.20)\end{array}$ & $\begin{array}{l}1.21 * * \\
(2.36)\end{array}$ & $\begin{array}{l}1.53 * * \\
(2.93)\end{array}$ & $\begin{array}{l}1.10^{* *} \\
(2.67)\end{array}$ & $\begin{array}{l}1.54 * * \\
(2.91)\end{array}$ & $\begin{array}{c}0.42 * * \\
(7.04)\end{array}$ & $\begin{array}{c}0.54^{* *} \\
(5.01)\end{array}$ \\
\hline $\mathrm{R}^{2}$ & 0.09 & 0.13 & 0.41 & 0.18 & 0.42 & 0.29 & 0.31 \\
\hline Observations & 44 & 44 & 44 & 44 & 44 & 44 & 44 \\
\hline
\end{tabular}

Absolute values of robust t-statistics are given in parentheses.

$*$ denotes significance at 10 percent, $* *$ denotes significance at 5 percent. 
Table 5. Results for Bank Claims on Private Sector

Dependent Variable: Claims by Banks on Private Sector / GDP

\begin{tabular}{|c|c|c|c|c|c|c|c|}
\hline Explanatory Variables & 1 & 2 & 3 & 4 & 5 & 6 & 7 \\
\hline $\mathrm{G}_{\mathrm{OV}}$ & $\begin{array}{c}-0.71 * * \\
(2.71)\end{array}$ & $\begin{array}{l}-0.52 \\
(1.54)\end{array}$ & $\begin{array}{c}-0.84^{* *} \\
(2.85)\end{array}$ & $\begin{array}{c}-0.66^{* *} \\
(2.73)\end{array}$ & $\begin{array}{c}-0.84 * * \\
(2.78)\end{array}$ & & \\
\hline $\mathrm{G}_{\mathrm{DS}}$ & & & & & & & $\begin{array}{c}-0.28^{* *} \\
(2.72)\end{array}$ \\
\hline French legal origin & & $\begin{array}{l}-0.04 \\
(0.84)\end{array}$ & $\begin{array}{l}-0.01 \\
(0.17)\end{array}$ & & $\begin{array}{l}-0.01 \\
(0.13)\end{array}$ & $\begin{array}{l}-0.02 \\
(0.65)\end{array}$ & $\begin{array}{l}-0.01 \\
(0.20)\end{array}$ \\
\hline German legal origin & & $\begin{array}{c}0.09 \\
(1.38)\end{array}$ & $\begin{array}{l}-0.03 \\
(0.55)\end{array}$ & & $\begin{array}{l}-0.04 \\
(0.64)\end{array}$ & $\begin{array}{l}0.10^{* *} \\
(2.07)\end{array}$ & $\begin{array}{c}0.00 \\
(0.00)\end{array}$ \\
\hline Institutions & & & $\begin{array}{c}0.14^{* *} \\
(4.90)\end{array}$ & & $\begin{array}{c}0.13 * * \\
(3.94)\end{array}$ & $\begin{array}{l}0.12 * * \\
(3.44)\end{array}$ & $\begin{array}{c}0.15^{* *} \\
(3.89)\end{array}$ \\
\hline Absolute latitude & & & & $\begin{array}{l}0.01^{*} \\
(2.00)\end{array}$ & $\begin{array}{c}0.00 \\
(0.39)\end{array}$ & $\begin{array}{c}0.00 \\
(0.42)\end{array}$ & $\begin{array}{c}0.00 \\
(0.14)\end{array}$ \\
\hline Landlocked & & & & $\begin{array}{c}-0.13 \\
(6.03)^{* *}\end{array}$ & $\begin{array}{l}-0.04 \\
(0.98)\end{array}$ & $\begin{array}{l}-0.04 \\
(1.27)\end{array}$ & $\begin{array}{l}-0.05 \\
(0.85)\end{array}$ \\
\hline Constant & $\begin{array}{c}0.88 * * \\
(3.68)\end{array}$ & $\begin{array}{l}0.74 * * \\
(2.45)\end{array}$ & $\begin{array}{l}1.01 * * \\
(3.93)\end{array}$ & $\begin{array}{c}0.77 * * \\
(3.31)\end{array}$ & $\begin{array}{c}0.99 * * \\
(3.76)\end{array}$ & $\begin{array}{c}0.26^{* *} \\
(6.10)\end{array}$ & $\begin{array}{c}0.47^{* *} \\
(5.02)\end{array}$ \\
\hline $\mathrm{R}^{2}$ & 0.09 & 0.12 & 0.47 & 0.24 & 0.47 & 0.38 & 0.47 \\
\hline Observations & 44 & 44 & 44 & 44 & 44 & 44 & 44 \\
\hline
\end{tabular}

Absolute values of robust t-statistics are given in parentheses.

* denotes significance at 10 percent, ${ }^{* *}$ denotes significance at 5 percent. 
Table 6. Results for All Financial Claims on Private Sector

\begin{tabular}{|c|c|c|c|c|c|c|c|}
\hline \multirow[b]{2}{*}{ Explanatory Variables } & \multicolumn{7}{|c|}{$\begin{array}{l}\text { Dependent Variable: All Financial Claims on Private } \\
\text { Sector / GDP }\end{array}$} \\
\hline & 1 & 2 & 3 & 4 & 5 & 6 & 7 \\
\hline $\mathrm{G}_{\mathrm{OV}}$ & $\begin{array}{l}-0.88 \\
(1.64)\end{array}$ & $\begin{array}{l}-0.24 \\
(0.56)\end{array}$ & $\begin{array}{l}-0.60 \\
(1.55)\end{array}$ & $\begin{array}{l}-0.81^{*} \\
(1.79)\end{array}$ & $\begin{array}{l}-0.60 \\
(1.54)\end{array}$ & & \\
\hline $\mathrm{G}_{\mathrm{DS}}$ & & & & & & & $\begin{array}{l}-0.20 \\
(1.39)\end{array}$ \\
\hline French legal origin & & $\begin{array}{l}-0.08 \\
(1.23)\end{array}$ & $\begin{array}{l}-0.04 \\
(0.75)\end{array}$ & & $\begin{array}{l}-0.04 \\
(0.68)\end{array}$ & $\begin{array}{l}-0.05 \\
(0.99)\end{array}$ & $\begin{array}{l}-0.04 \\
(0.77)\end{array}$ \\
\hline German legal origin & & $\begin{array}{c}0.42 * * \\
(4.77)\end{array}$ & $\begin{array}{c}0.28^{* *} \\
(3.60)\end{array}$ & & $\begin{array}{c}0.28^{* *} \\
(3.09)\end{array}$ & $\begin{array}{c}0.38^{* *} \\
(5.80)\end{array}$ & $\begin{array}{c}0.31 * * \\
(3.49)\end{array}$ \\
\hline Institutions & & & $\begin{array}{c}0.16^{* *} \\
(4.70)\end{array}$ & & $\begin{array}{c}0.16^{* *} \\
(3.86)\end{array}$ & $\begin{array}{c}0.15^{* *} \\
(3.53)\end{array}$ & $\begin{array}{c}0.17 * * \\
(3.55)\end{array}$ \\
\hline Absolute latitude & & & & $\begin{array}{l}0.01 * \\
(1.97)\end{array}$ & $\begin{array}{c}0.00 \\
(0.06)\end{array}$ & $\begin{array}{c}0.00 \\
(0.09)\end{array}$ & $\begin{array}{c}0.00 \\
(0.07)\end{array}$ \\
\hline Landlocked & & & & $\begin{array}{c}-0.17^{* *} \\
(4.84)\end{array}$ & $\begin{array}{l}-0.04 \\
(0.75)\end{array}$ & $\begin{array}{l}-0.04 \\
(1.02)\end{array}$ & $\begin{array}{l}-0.05 \\
(0.72)\end{array}$ \\
\hline Constant & $\begin{array}{l}1.08^{* *} \\
(2.24)\end{array}$ & $\begin{array}{c}0.56 \\
(1.46)\end{array}$ & $\begin{array}{c}0.87 * * \\
(2.62)\end{array}$ & $\begin{array}{c}0.93^{* *} \\
(2.29)\end{array}$ & $\begin{array}{c}0.87^{* *} \\
(2.56)\end{array}$ & $\begin{array}{c}0.35^{* *} \\
(6.13)\end{array}$ & $\begin{array}{c}0.49 * * \\
(3.83)\end{array}$ \\
\hline $\mathrm{R}^{2}$ & 0.08 & 0.23 & 0.50 & 0.22 & 0.50 & 0.47 & 0.49 \\
\hline Observations & 44 & 44 & 44 & 44 & 44 & 44 & 44 \\
\hline
\end{tabular}

Absolute values of robust t-statistics are given in parentheses.

* denotes significance at 10 percent, ${ }^{* *}$ denotes significance at 5 percent. 
Table 7. Results for Net Interest Margin

\begin{tabular}{|c|c|c|c|c|c|c|c|}
\hline \multirow[b]{2}{*}{ Explanatory Variables } & \multicolumn{7}{|c|}{ Dependent Variable: Net Interest Margin } \\
\hline & 1 & 2 & 3 & 4 & 5 & 6 & 7 \\
\hline $\mathrm{G}_{\mathrm{OV}}$ & $\begin{array}{c}0.22 * * \\
(4.13)\end{array}$ & $\begin{array}{c}0.21 * * \\
(2.91)\end{array}$ & $\begin{array}{c}0.24^{* *} \\
(3.80)\end{array}$ & $\begin{array}{c}0.21^{* *} \\
(3.61)\end{array}$ & $\begin{array}{c}0.24 * * \\
(3.69)\end{array}$ & & \\
\hline $\mathrm{G}_{\mathrm{DS}}$ & & & & & & & $\begin{array}{c}0.08^{* *} \\
(3.59)\end{array}$ \\
\hline French legal origin & & $\begin{array}{c}0.01 \\
(1.00)\end{array}$ & $\begin{array}{c}0.01 \\
(0.62)\end{array}$ & & $\begin{array}{c}0.00 \\
(0.60)\end{array}$ & $\begin{array}{c}0.01 \\
(1.57)\end{array}$ & $\begin{array}{c}0.01 \\
(0.86)\end{array}$ \\
\hline German legal origin & & $\begin{array}{c}0.01 \\
(0.99)\end{array}$ & $\begin{array}{c}0.02 * * \\
(2.03)\end{array}$ & & $\begin{array}{l}0.02 * \\
(1.71)\end{array}$ & $\begin{array}{c}-0.02 \\
(1.58)\end{array}$ & $\begin{array}{c}0.01 \\
(0.91)\end{array}$ \\
\hline Institutions & & & $\begin{array}{c}-0.01 * * \\
(2.10)\end{array}$ & & $\begin{array}{l}-0.01 * \\
(1.73)\end{array}$ & $\begin{array}{c}-0.01 \\
(0.98)\end{array}$ & $\begin{array}{c}-0.02 * * \\
(2.22)\end{array}$ \\
\hline Absolute latitude & & & & $\begin{array}{c}0.00 \\
(0.54)\end{array}$ & $\begin{array}{c}0.00 \\
(0.26)\end{array}$ & $\begin{array}{c}0.00 \\
(0.03)\end{array}$ & $\begin{array}{c}0.00 \\
(0.66)\end{array}$ \\
\hline Landlocked & & & & $\begin{array}{c}0.00 \\
(0.72)\end{array}$ & $\begin{array}{l}-0.01 \\
(0.95)\end{array}$ & $\begin{array}{c}0.00 \\
(0.27)\end{array}$ & $\begin{array}{l}-0.02 \\
(1.46)\end{array}$ \\
\hline Constant & $\begin{array}{c}-0.14 * * \\
(3.03)\end{array}$ & $\begin{array}{c}-0.14 * * \\
(2.19)\end{array}$ & $\begin{array}{c}-0.16^{* *} \\
(2.97)\end{array}$ & $\begin{array}{c}-0.13 * * \\
(2.47)\end{array}$ & $\begin{array}{c}-0.17 * * \\
(2.89)\end{array}$ & $\begin{array}{l}0.04 * * \\
(4.19)\end{array}$ & $\begin{array}{l}-0.02 \\
(1.02)\end{array}$ \\
\hline $\mathrm{R}^{2}$ & 0.26 & 0.29 & 0.36 & 0.27 & 0.37 & 0.16 & 0.35 \\
\hline Observations & 37 & 37 & 37 & 37 & 37 & 37 & 37 \\
\hline
\end{tabular}

Absolute values of robust t-statistics are given in parentheses.

* denotes significance at 10 percent, ${ }^{* *}$ denotes significance at 5 percent. 
Table 8. Results for Overhead Costs

\begin{tabular}{|c|c|c|c|c|c|c|c|}
\hline \multirow[b]{2}{*}{ Explanatory Variables } & \multicolumn{7}{|c|}{ Dependent Variable: Overhead Costs/Bank Assets } \\
\hline & 1 & 2 & 3 & 4 & 5 & 6 & 7 \\
\hline $\mathrm{G}_{\mathrm{OV}}$ & $\begin{array}{c}0.19^{* *} \\
(2.22)\end{array}$ & $\begin{array}{c}0.18 \\
(1.58)\end{array}$ & $\begin{array}{l}0.20^{*} \\
(1.80)\end{array}$ & $\begin{array}{c}0.18^{*} \\
(1.90)\end{array}$ & $\begin{array}{c}0.20^{*} \\
(1.71)\end{array}$ & & \\
\hline $\mathrm{G}_{\mathrm{DS}}$ & & & & & & & $\begin{array}{l}0.07^{*} \\
(1.97)\end{array}$ \\
\hline French legal origin & & $\begin{array}{c}0.01 \\
(0.88)\end{array}$ & $\begin{array}{c}0.01 \\
(0.49)\end{array}$ & & $\begin{array}{c}0.01 \\
(0.49)\end{array}$ & $\begin{array}{c}0.01 \\
(1.16)\end{array}$ & $\begin{array}{c}0.01 \\
(0.77)\end{array}$ \\
\hline German legal origin & & $\begin{array}{c}0.01 \\
(0.37)\end{array}$ & $\begin{array}{c}0.02 \\
(0.80)\end{array}$ & & $\begin{array}{c}0.02 \\
(0.82)\end{array}$ & $\begin{array}{c}-0.02 \\
(1.56)\end{array}$ & $\begin{array}{c}0.01 \\
(0.38)\end{array}$ \\
\hline Institutions & & & $\begin{array}{c}-0.01 \\
(1.03)\end{array}$ & & $\begin{array}{l}-0.01 \\
(0.97)\end{array}$ & $\begin{array}{c}0.00 \\
(0.48)\end{array}$ & $\begin{array}{l}-0.01 \\
(1.37)\end{array}$ \\
\hline Absolute latitude & & & & $\begin{array}{c}0.00 \\
(0.57)\end{array}$ & $\begin{array}{c}0.00 \\
(0.09)\end{array}$ & $\begin{array}{c}0.00 \\
(0.24)\end{array}$ & $\begin{array}{c}0.00 \\
(0.22)\end{array}$ \\
\hline Landlocked & & & & $\begin{array}{c}0.00 \\
(0.45)\end{array}$ & $\begin{array}{c}-0.01 \\
(0.57)\end{array}$ & $\begin{array}{c}0.00 \\
(0.39)\end{array}$ & $\begin{array}{l}-0.01 \\
(0.91)\end{array}$ \\
\hline Constant & $\begin{array}{l}-0.11 \\
(1.52)\end{array}$ & $\begin{array}{c}-0.11 \\
(1.08)\end{array}$ & $\begin{array}{l}-0.13 \\
(1.30)\end{array}$ & $\begin{array}{l}-0.11 \\
(1.18)\end{array}$ & $\begin{array}{c}-0.13 \\
(1.22)\end{array}$ & $\begin{array}{c}0.05^{* *} \\
(4.14)\end{array}$ & $\begin{array}{c}0.00 \\
(0.03)\end{array}$ \\
\hline $\mathrm{R}^{2}$ & 0.15 & 0.20 & 0.20 & 0.16 & 0.20 & 0.10 & 0.19 \\
\hline Observations & 38 & 38 & 38 & 38 & 38 & 38 & 38 \\
\hline
\end{tabular}

Absolute values of robust t-statistics are given in parentheses.

* denotes significance at 10 percent, ${ }^{* *}$ denotes significance at 5 percent. 
Table 9. Land Inequality vs. Income Inequality

\begin{tabular}{|c|c|c|c|c|c|}
\hline & $\begin{array}{l}\text { Liquid } \\
\text { Liabilities/ } \\
\text { GDP }\end{array}$ & $\begin{array}{l}\text { Bank } \\
\text { Credit/ } \\
\text { GDP }\end{array}$ & $\begin{array}{c}\text { Claims on } \\
\text { Private } \\
\text { Sector/ GDP }\end{array}$ & $\begin{array}{c}\text { Net } \\
\text { Interest } \\
\text { Margin }\end{array}$ & $\begin{array}{c}\text { Overhead/ } \\
\text { Bank } \\
\text { Assets }\end{array}$ \\
\hline Explanatory Variables & 1 & 2 & 3 & 4 & 5 \\
\hline $\mathrm{G}_{\mathrm{OV}}$ & $\begin{array}{l}-0.85 \\
(1.25)\end{array}$ & $\begin{array}{c}-1.46^{* *} \\
(2.60)\end{array}$ & $\begin{array}{c}-1.53^{* *} \\
(2.05)\end{array}$ & $\begin{array}{c}0.23 * * \\
(2.60)\end{array}$ & $\begin{array}{c}0.24 * * \\
(2.09)\end{array}$ \\
\hline Income Gini & $\begin{array}{l}-0.03 \\
(0.09)\end{array}$ & $\begin{array}{l}0.61 * \\
(1.86)\end{array}$ & $\begin{array}{l}1.08 * * \\
(2.14)\end{array}$ & $\begin{array}{c}0.04 \\
(0.57)\end{array}$ & $\begin{array}{l}-0.01 \\
(0.10)\end{array}$ \\
\hline French legal origin & $\begin{array}{l}-0.07 \\
(0.97)\end{array}$ & $\begin{array}{l}-0.03 \\
(0.59)\end{array}$ & $\begin{array}{l}-0.09 \\
(1.39)\end{array}$ & $\begin{array}{c}0.01 \\
(0.86)\end{array}$ & $\begin{array}{c}0.01 \\
(1.32)\end{array}$ \\
\hline German legal origin & $\begin{array}{l}-0.22 \\
(1.54)\end{array}$ & $\begin{array}{l}-0.10 \\
(1.01)\end{array}$ & $\begin{array}{c}0.17 \\
(1.29)\end{array}$ & $\begin{array}{c}0.03 \\
(2.11)\end{array}$ & $\begin{array}{c}0.03 \\
(1.81)\end{array}$ \\
\hline Institutions & $\begin{array}{l}0.12 * * \\
(2.20)\end{array}$ & $\begin{array}{l}0.10^{* *} \\
(2.05)\end{array}$ & $\begin{array}{l}0.13^{* *} \\
(2.22)\end{array}$ & $\begin{array}{l}-0.01 \\
(1.62)\end{array}$ & $\begin{array}{c}0.0 \\
(0.07)\end{array}$ \\
\hline Absolute latitude & $\begin{array}{c}0.0 \\
(0.69)\end{array}$ & $\begin{array}{c}0.0 \\
(0.32)\end{array}$ & $\begin{array}{c}0.0 \\
(0.3)\end{array}$ & $\begin{array}{c}0.0 \\
(0.13)\end{array}$ & $\begin{array}{c}0.0 \\
(0.69)\end{array}$ \\
\hline Landlocked & $\begin{array}{c}-0.16^{* *} \\
(3.09)\end{array}$ & $\begin{array}{c}-0.09 * \\
(1.75)\end{array}$ & $\begin{array}{l}-0.08 \\
(1.33)\end{array}$ & & \\
\hline Constant & $\begin{array}{c}1.16^{* *} \\
(2.2)\end{array}$ & $\begin{array}{l}1.30^{* *} \\
(2.84)\end{array}$ & $\begin{array}{l}1.25^{* *} \\
(2.16)\end{array}$ & $\begin{array}{l}-0.18 * * \\
(2.57)\end{array}$ & $\begin{array}{l}-0.17^{*} \\
(1.78)\end{array}$ \\
\hline $\begin{array}{l}\mathrm{R}^{2} \\
\text { Observations }\end{array}$ & $\begin{array}{c}0.67 \\
32\end{array}$ & $\begin{array}{c}0.46 \\
32\end{array}$ & $\begin{array}{c}0.57 \\
32\end{array}$ & $\begin{array}{c}0.44 \\
29\end{array}$ & $\begin{array}{c}0.39 \\
30\end{array}$ \\
\hline
\end{tabular}

Absolute values of robust t-statistics are given.

* denotes significance at 10 percent, $* *$ denotes significance at 5 percent. 


\section{REFERENCES}

Acemoglu, D., S. Johnson, and J.A. Robinson, 2001, “The Colonial Origins of Comparative Development: An Empirical Investigation," American Economic Review 91(5), pp. 1369-401.

Banerjee, A. and L. Iyer, 2005, "History, Institutions and Economic Performance: The Legacy of Colonial Land Tenure Systems in India," American Economic Review, 95(4), pp. 1190-213.

Beck, T., R. Levine, and N. Loayza, 2000, "Finance and the Sources of Growth," Journal of Financial Economics 58, pp. 261-300.

Bell, C.,1988, "Credit Markets and Interlinked Transactions," in Handbook of Development Economics, H. Chenery and T. N. Srinivasan, eds., Vol. 1, North-Holland, pp. 763-830.

Berry, R. A., and W.R. Cline, 1979, “Agrarian Structure and Productivity in Developing Countries" (Baltimore: Johns Hopkins University Press).

Besley, T. J., 1998, "How do Market Failures Justify Interventions in Rural Credit Markets?" in "International Agricultural Development," C. K. Eicher and J. M. Staatz, eds., pp. 370-389 (Baltimore: Johns Hopkins University Press).

Besley, T.J., and R. Burgess, 2000, "Land Reform, Poverty Reduction and Growth: Evidence from India" Quarterly Journal of Economics 115 pp. 389-430.

Binswanger, H. P., K. Deininger, and G. Feder, 1995, "Power, Distortions, Revolt and Reform in Agricultural Land Relations," in J. Behrman and T. N. Srinivasan, eds., Handbook of Development Economic, Volume III, Elsevier, Amsterdam.

Bulmer-Thomas, V., 2003, "The Economic History of Latin America since Independence" (Cambridge: Cambridge University Press).

Chakraborty, S., and T. Ray, 2006, "The Development and Structure of Financial Systems," Journal of Economic Dynamics and Control, forthcoming.

de Janvry, A., and E. Sadoulet, 1989, “A Study in Resistance to Institutional Change: The Lost Game of Latin American Land Reform," World Development, 17, pp. 1397-407.

de Janvry, A., J. Platteau, G. Gordillo, and E. Sadoulet, 2001, “Access to Land and Land Policy Reforms," in de J. Janvry, G. Gordillo, J. Platteau, and E. Sadoulet, eds., "Access to Land, Rural Poverty, and Public Action" (Oxford: Oxford University Press). 
Deininger, K., 2001, "Negotiated Land Reform as One Way of Land Access: Experiences from Colombia, Brazil, and South Africa," in de J. Janvry, G. Gordillo, J. Platteau, and E. Sadoulet, E., eds., "Access to land, Rural Poverty, and Public Action" (Oxford: Oxford University Press).

Deininger, K., and L. Squire, 1998, "New Ways of Looking at Old Issues: Inequality and Growth," Journal of Development Economics 57(2), pp. 259-87.

Easterly, W., and R. Levine, 2003, " Tropics, Germs, and Crops: The Role of Endowments in Economic Development," Journal of Monetary Economics 50(1).

Engerman, S. L., and K.L. Sokoloff, 1997, "Factor Endowments, Institutions, and Differential Paths of Growth Among New World Economies: A View from Economic Historians of the United States, in "How Latin America fell behind: Essays on the Economic Histories of Brazil and Mexico, 1800-914," S. Haber, ed., pp. 260-304 (California: Stanford University Press).

Erickson, L., and D. Vollrath, 2004, "Dimensions of Land Inequality and Economic Development," IMF Working Paper No. 04/158 (Washington: International Monetary Fund).

Food and Agriculture Organization (FAO), "Report of the World Census of Agriculture" 1950, 1960, 1970, 1980, 1990, and 2000.

Galor, O., O. Moav, and D. Vollrath, 2005, "Land Inequality and the Origin of Divergence and Overtaking in the Growth Process: Theory and Evidence," Brown Economics Working Paper.

Haber, S. H., 1991, "Industrial Concentration and the Capital Markets: A Comparative Study of Brazil, Mexico, and the United States, 1830-1930," Journal of Economic History Vol. 51(3), pp. 559-580.

Haber, S. H., 1997, "Financial Markets and Industrial Development: A Comparative Study of Governmental Regulation, Financial Innovation, and Industrial Structure in Brazil and Mexico, 1840-930. In How Latin America Fell Behind: Essays on the Economic Histories of Brazil and Mexico," 1800-914, ed. Stephen Haber, pp. 260-304 (California: Stanford University Press).

Jeon, Y., and Y. Kim, 2000, "Land Reform, Income Redistribution, and Agricultural Production in Korea, Economic Development and Cultural Change," Vol. 48, pp. 253-68.

Kaufman, D., A. Kraay, and P. Zoido, 1999, “Aggregating Governance Indicators.” World Bank Research Working Paper No. 2195 (Washington: World Bank). 
King, R. G., and R. Levine, 1993, "Finance and Growth: Schumpeter Might Be Right," Quarterly Journal of Economics 108, pp. 717-738.

La Porta, R., F. Lopez-de-Silanes, A. Shleifer, and R.W. Vishny, 1997, "Legal Determinants of External Finance," Journal of Finance 52, pp. 1131-150.

La Porta, R., F. Lopez-de-Silanes, A. Shleifer, and R.W. Vishny, 1998, "Law and finance," Journal of Political Economy 106, pp. 1113-155.

Levine, R., 1997, "Financial Development and Economic Growth: Views and Agenda," Journal of Economic Literature, 35(2), pp. 688-726.

Levine, R., 2005, "Finance and growth: Theory and evidence," in P. Aghion and S. N. Durlauf, eds., Handbook of Economic Growth, North-Holland, pp. 865-934.

Levine, R., and Demirguc-Kunt, A., eds., 2001, Financial Structure and Economic Growth: A Cross-Country Comparison of Banks, Markets and Development, MIT Press, Cambridge.

Levine, R., T. Beck, and N. Loayza, 2000, ’Financial Intermediation and Growth: Causality and Causes," Journal of Monetary Economics 46, pp. 31-77.

Levine, R., and S. Zervos, 1998, "Stock Markets, Banks, and Economic Growth," American Economic Review Vol. 88, pp. 537-558.

Otsuka, K., 1991, "Determinants and Consequences of Land Reform Implementation in the Philippines," Journal of Development Economics, 35, pp. 339-55.

Stiglitz, J., and A. Weiss, 1981, "Credit Rationing in Markets with Imperfect Information," American Economic Review, 71, pp. 393-410.

Tomich, T. P., P. Kilby, and B.F. Johnston, eds., 1995, “Transforming Agrarian Economies," Cornell University Press, Ithaca, NY.

United Nations, "United Nations Population Yearbook," 1987 and 1995.

Vollrath, D., 2007, "Land Distribution and International Agricultural Productivity," American Journal of Agricultural Economics, forthcoming. 